38. Petry, N., Egli, I., Campion, B., Nielsen, E. and Hurrell, R., Genetic reduction of phytate in common bean (Phaseolus vulgaris L.) seeds increases iron absorption in young women. Nutrition, 2013, 143(8), 1219-1224.

39. Sedef Nehir, E. I., Sibel, K. and Şebnem, S., Effect of phytic acid on iron bioavailability in fortified infant cereals. Nutrition Food Sci., 2010, 40(5), 485-493.

40. Afify, A. M., El-Beltagi, H. S., El-Salam, S. M. and Omran, A. A., Bioavailability of iron, zinc, phytate and phytase activity during soaking and germination of white sorghum varieties. PLOS ONE, 2011, 6(10), e25512; doi:10.1371/journal.pone.0025512.

41. Swamy, B. P. M. et al., Identification of genomic regions associated with agronomic and biofortification traits in $\mathrm{DH}$ populations of rice. PLoS ONE, 2018; https://doi.org/10.1371/ journal.pone.0201756.

42. Inabangan-Asilo, M. A. et al., Stability and $\mathrm{G} \times \mathrm{E}$ analysis of zincbiofortified rice genotypes evaluated in diverse environments. Euphytica, 2019, 215, 61; doi.org/10.1007/s10681-019-2384-7.

ACKNOWLEDGEMENTS. The work was financially supported by Indian Council for Agricultural Research, Government of India grant NPTC/FG/05/2672/33-3019 to S.N. We thank Dr N. K. Singh, coordinator of the network, Dr S. K. Mangrauthia, presently Co-PI and Dr S. R. Voleti, Director, Indian Institute of Rice Research for their constant support. We acknowledge All India Co-ordinated Rice Improvement Project, Indian Institute of Rice Research, Hyderabad for multilocation evaluation in national biofortification trials.

\section{A significant shift in particulate organic matter characteristics during flooding of River Krishna, eastern peninsular India}

\author{
C. Prakash Babu ${ }^{1, *}$, V. Ramaswamy ${ }^{2}$, P. S. Rao ${ }^{3}$, \\ V. V. S. S. Sarma ${ }^{4}$ and P. Praveen Kumar \\ ${ }^{1}$ CSIR-National Institute of Oceanography, Dona Paula, \\ Goa 403 004, India \\ ${ }^{2}$ A-6, Oceanis Society, Bambolim, Goa 403 202, India \\ ${ }^{3}$ Flat No. 502, First Block, Kamat Riviera, Caranzalem, \\ Goa 403 002, India \\ ${ }^{4}$ CSIR-National Institute of Oceanography, Regional Centre, \\ Visakhapatnam 530 017, India \\ ${ }^{5}$ National Institute of Animal Biotechnology, \\ Hyderabad 500 049, India
}

Extremely heavy rainfall over a small, semi-arid section of the Indian Peninsula in October 2009, together with release of water from dams resulted in very severe flooding in River Krishna. The sources and

*For correspondence. (e-mail: pbabu@nio.org) type of organic matter during and after the floods were studied by analysing suspended particulate matter (SPM) for organic carbon $(C)$, total nitrogen $(\mathrm{N})$ and isotopic composition of $C\left(\delta^{13} C_{o r g}\right)$. The $\delta^{13} C_{\text {org }}$ varied from $-21.4 \%$ during the initial heavy flood phase to $-\mathbf{2 7 . 1 \%}$ in the final receding phase. Discharge of terrestrial carbon $(-21.4 \%$ to $-23.5 \%)$ from mixed sources with high $\mathrm{C} / \mathrm{N}$ ratios (14-19) during the initial phase of the flood originated from the semi-arid section of the river. The light carbon $(-25.5 \%$ to $-27.1 \%$ ) with low $\mathrm{C} / \mathrm{N}$ ratios $(7.2-9.5)$ in the receding phase of the flood was from local $\mathrm{C} 3$-rich organic debris from the deltaic regions along with phytoplankton from aquatic sources. Since the average suspended sediment discharge of River Krishna has decreased from $68 \mathrm{mt}$ to less than $0.1 \mathrm{mt}$ due to construction of dams and barrages, it appears that sediments and organic matter presently being delivered to the oceans are mainly during flood events, and the type of organic matter delivered depends on the nature of the soil where high rainfall is received.

Keywords: Carbon isotopes, extreme rainfall events rivers, floods, particulate organic matter.

RIVERS play an important role in transporting sediments and organic matter from land to sea. Fluvial carbon is the biggest source of organic carbon in continental margin sediments. The total global fluvial carbon flux is 0.80 $1.33 \mathrm{Pg} \mathrm{C} /$ year (ref. 1). During the last century, dams were built across most rivers of the world, including peninsular Indian rivers, resulting in significant reduction in water, sediment and organic carbon delivery to the oceans $^{2}$. River Krishna is an extreme example of this, as more than 650 small and large dams have been constructed across this river during the last 60 years. Since 2002, the holding capacity of the dams by River Krishna nearly equals or exceeds the annual run-off ${ }^{3-5}$. Understanding the amount and nature of carbon in such river basins is important as reduction in carbon supply affects the estuarine and near-coastal environment.

Soil carbon, aquatic plants, agriculture, vascular plants, bacteria, etc. are the main sources of terrestrial organic carbon $^{6-8}$. The soil type, agriculture, vegetation, precipitation, temperature and weathering rates dictate the nature of organic matter in fluvial environment. The $\mathrm{C} / \mathrm{N}$ (organic carbon/nitrogen) ratio and $\delta^{13} \mathrm{C}_{\text {org }}$ (isotopic composition of organic carbon) are commonly adopted to characterize the organic carbon sources ${ }^{9-12}$. Relatively lower $\delta^{13} \mathrm{C}_{\text {org }}$ ranging from $-23 \%$ o to $-33 \%$, with an average of $-27 \%$ o characterizes the $\mathrm{C} 3$ organic matter ${ }^{13-15}$, while plants employing $\mathrm{C} 4$ pathway are distinguished by $\delta^{13} \mathrm{C}_{\text {org }}$ enrichment ranging from $-9 \%$ to $-17 \%$ (refs $13,14,16-18$ ). Freshwater phytoplankton has $\delta^{13} \mathrm{C}_{\text {org }}$ values between $-25 \%$ and $-30 \%$ and relatively low $\mathrm{C} / \mathrm{N}$ ratios (5$10)^{18,19}$. On the other hand, soil organic matter (SOM) has high $\mathrm{C} / \mathrm{N}$ ratios $(>12)^{20}$. 


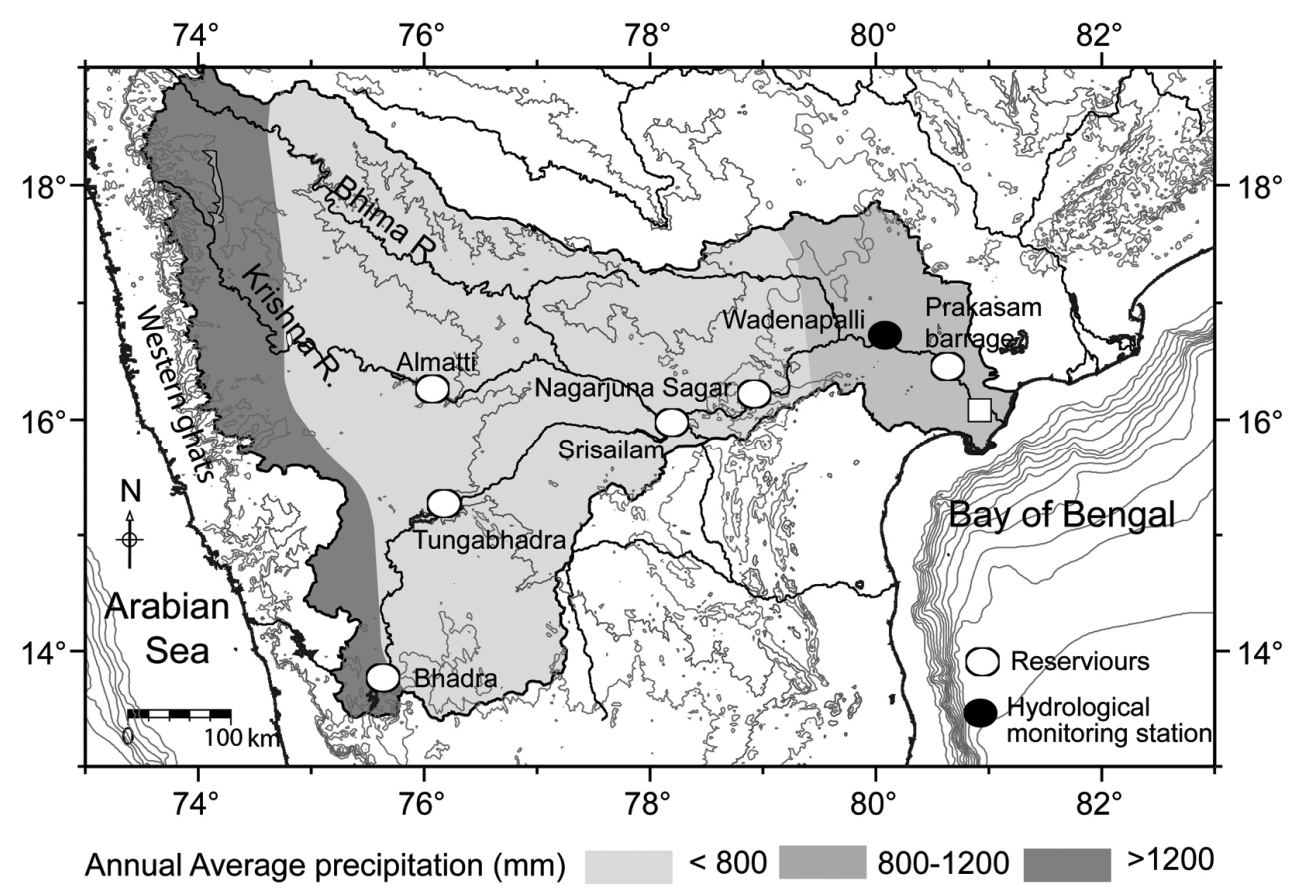

Figure 1. Map showing River Krishna and its tributaries. Location of the suspended particulate matter sampling is shown as a square. Different shades of grey represent the annual average precipitation (mm) along the Krishna river basin for the period 1951-2003 (refs 36, 37). The depth contours are at $200 \mathrm{~m}$ interval.

River Krishna, after its origin in the Western Ghats rainforests (annual rainfall $>2500 \mathrm{~mm}$ ), flows mainly through a semi-arid Deccan Plateau $(<600 \mathrm{~mm}$ annual rainfall) for most of its length till it reaches the deltaic regions, where rainfall increases to about $800 \mathrm{~mm} /$ year (Figure 1). Over $80 \%$ of rainfall in the Krishna River Basin occurs during the summer monsoon period (JuneSeptember). Sediments as well as organic matter in River Krishna are discharged mainly during this period. Construction of dams and barrages along this river has drastically altered the flow of freshwater to the Bay of Bengal (BOB). Sediment delivery has reduced from $68 \mathrm{mt}$ before 1960 to $<0.1 \mathrm{mt}$ during the last decade ${ }^{4,21-23}$. A compilation of discharge for the past 50 years also shows a general decreasing trend along River Krishna ${ }^{23-25}$. The suspended load at Wadenapalli during the last decade has drastically reduced to $<0.1 \mathrm{mt}$ (ref. 26) from $68 \mathrm{mt}$ before the 1960s (ref. 21).

In recent years, a number of extreme rainfall events and associated flash floods have been recorded in India, including those of Mumbai 2005, Raichur 2009, Uttarakhand 2013, and Kashmir 2014 and 2015. In 2009, the semi-arid regions of River Krishna experienced unprecedented rainfall of 33-57 cm within 3-4 days (30 September-3 October) compared to an average monthly rainfall of 7-13 cm (Figure 2) ${ }^{27}$. High rainfall in a short span of time led to high water levels in the dams, forcing abrupt release of water from reservoirs and causing intense flooding in the lower regions. Cascading effect led to the highest water levels in the Srisailam dam on 30 September,
Nagarjuna Sagar dam on 3 October and Prakasam Barrage on 6 October $^{27}$. Water inflow of nearly $31,000 \mathrm{~m}^{3} \mathrm{~s}^{-1}$ was recorded at the Prakasam Barrage on 6 October 2009 (ref. 27) against an annual average flow of $2213 \mathrm{~m}^{3} \mathrm{~s}^{-1}$ (ref. 28). The high inflow surpassed all previous records of water flow, including the great flood of 1903 which occurred before the dams were built ${ }^{27}$. The flood water breached the river banks at several places, thereby inundating several low-lying areas and populated regions (Figure $3 a$ ). With decrease in precipitation and regulation of water release from the dams since 15 October 2009, water discharge returned to normal levels by the end of October 2009 (Figure 3 b). Significant sediment load and suspended organic matter were delivered to the oceans during the extreme precipitation and discharge periods. The impact of high discharge caused by River Godavari to the coastal western $\mathrm{BOB}$ has been reported earlier ${ }^{29}$. The objective of the present study is to assess the shift in the characteristics of suspended particulate matter (SPM) and organic matter delivered to the coastal BOB during severe flooding of River Krishna.

SPM was collected in the Krishna Estuary from a bridge $\left(16.033^{\circ} \mathrm{N} ; 80.873^{\circ} \mathrm{E}\right.$; Figure 1) about $60 \mathrm{~km}$ downstream of the Prakasam Barrage. Sampling was done on alternate days starting from 9 October 2009 till 27 October 2009 (Table 1). Sampling could not be carried out for the first week after the flood as the area was inaccessible. Surface water was collected in large clean plastic buckets and suspended matter allowed to settle for a day. The clear water was decanted, while the remaining 


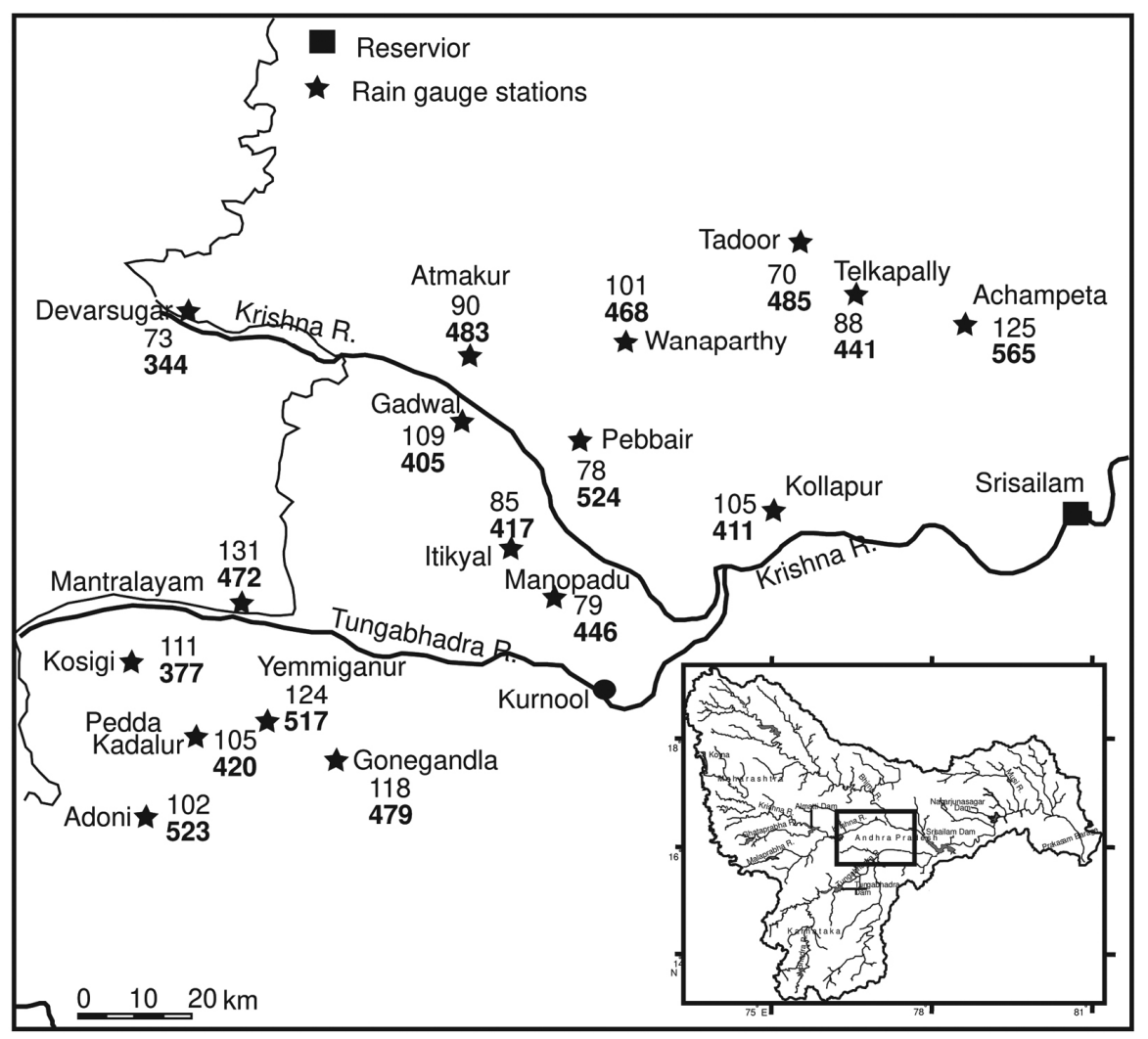

Figure 2. Map showing high precipitation ( $\mathrm{mm}$, bold numbers) during four days. (30 September-3 October 2009) compared to normal rainfall $(\mathrm{mm})$ in the semi-arid Krishna River basin ${ }^{27}$. (Data source: Department of Economics and Statistics, Government of Andhra Pradesh). (Inset) Krishna River basin.
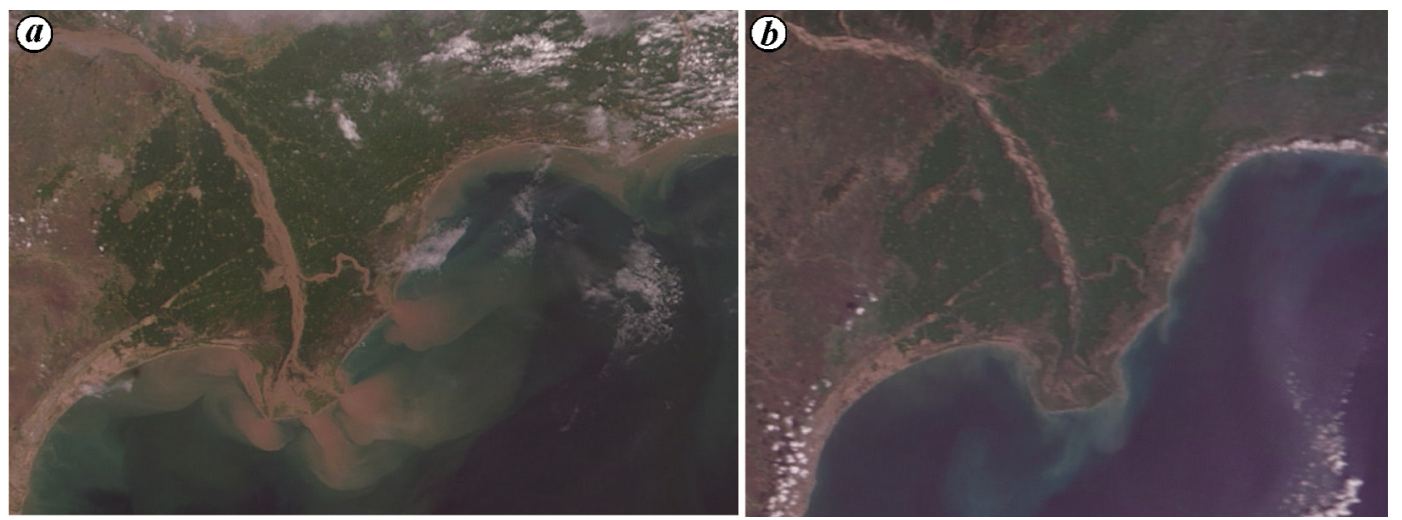

Figure 3. $\boldsymbol{a}$, Satellite image (Modis Terra True Color image $1 \mathrm{~km}$ ) of 7 October 2009 showing suspended sediment being discharged into the Bay of Bengal during the peak flood period. $\boldsymbol{b}$, Satellite image (Modis Terra True Color Image $250 \mathrm{~m}$ ) of 24 October 2009 showing noticeable reduction of suspended sediment discharge during the receding phase of flood.

slurry transferred to acid-cleaned plastic bottles and stored in a refrigerator. The slurry was filtered onto $0.4 \mu \mathrm{m}$ polycarbonate filters and while still wet removed from the filter using a plastic blade and subsequently freeze-dried and powdered.

Total carbon and nitrogen, and inorganic carbon (TIC) contents were measured using an elemental analyser (Carlo-Erba NCS 2500, Italy) and coulometer (UIC $\mathrm{CO}_{2}$
5014) respectively. The analytical precision and accuracy based on replicate analysis and international reference material (MAG-1 and SGR-1) is within $\pm 5 \%$. Organic carbon content (\%) was calculated as the difference between total carbon and TIC. Another aliquot of the particulate matter was washed repeatedly with $1 \mathrm{~N} \mathrm{HCl}$ and distilled water for removing calcium carbonate before measuring $\delta^{13} \mathrm{C}_{\text {org }}$. The complete removal of carbonate 

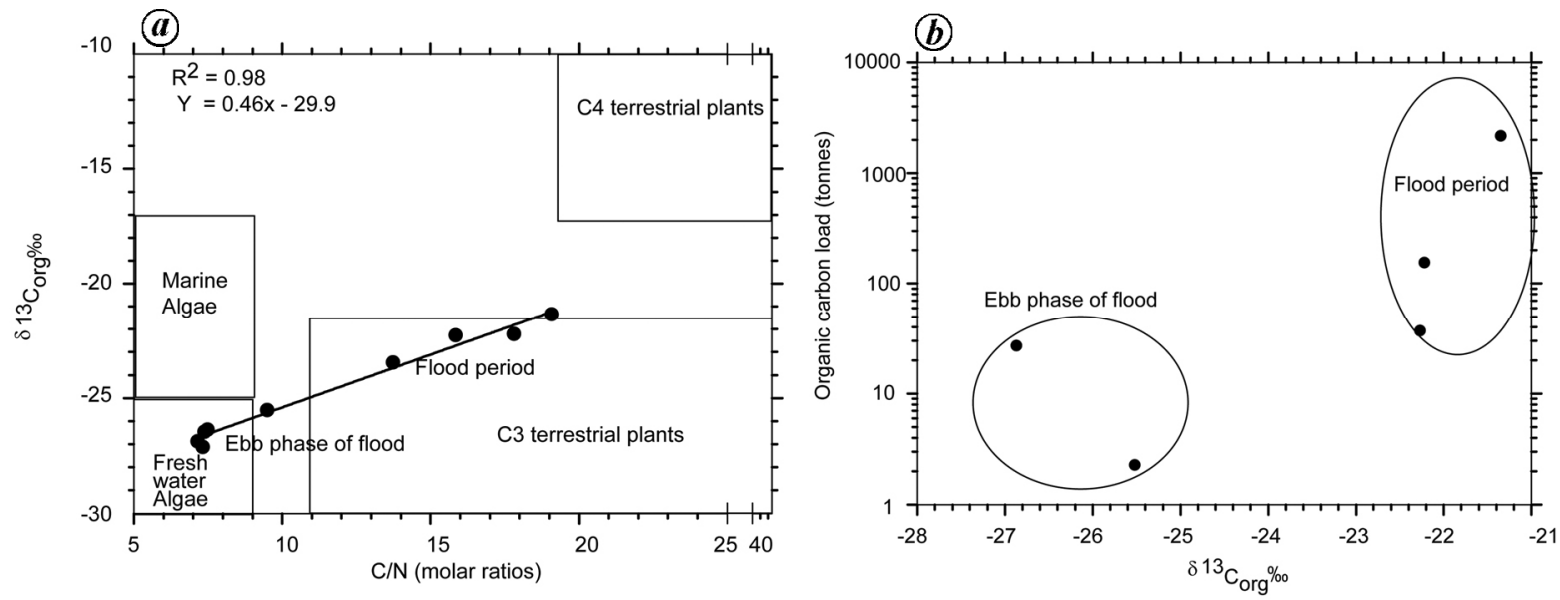

Figure 4. $\quad \boldsymbol{a}, X-Y$ plot of $\mathrm{C} / \mathrm{N}$ ratios versus $\delta^{13} \mathrm{C}_{\text {org }}(\%$ o) of the Krishna River particulate matter collected during October 2009. Notice a drastic change in the terrestrial organic matter sources during the peak and receding phase of the floods. The $\delta^{13} \mathrm{C}_{\text {org }}(\%)$ values for $\mathrm{C} 3$ and C4-type plants are obtained from the literature ${ }^{18}$. b. Differences in the terrestrial carbon load during flood and receding phase of the October 2009 flood.

Table 1. Details of total suspended particulate matter (SPM) collected during the great October 2009 flood along with elemental and carbon isotope data. Total suspended load (million tonnes) and organic carbon load during the flood period are also provided

\begin{tabular}{|c|c|c|c|c|c|c|c|c|c|c|}
\hline Sample ID & $\begin{array}{c}\text { Date of } \\
\text { collection }\end{array}$ & $\begin{array}{l}\text { Latitude } \\
\text { (N) }\end{array}$ & $\begin{array}{l}\text { Longitude } \\
\text { (E) }\end{array}$ & $\begin{array}{c}\text { SPM } \\
\text { wt (mg/l) }\end{array}$ & $\begin{array}{c}\text { Nitrogen } \\
(\mathrm{wt} \%)\end{array}$ & $\begin{array}{c}\text { Organic } \\
\text { carbon }(\mathrm{wt} \%)\end{array}$ & $\begin{array}{c}\mathrm{C} / \mathrm{N} \\
\text { (molar ratio) }\end{array}$ & $\begin{array}{c}\delta^{13} \mathrm{C}_{\text {org }} \% \text { o } \\
\text { versus PDB }\end{array}$ & $\begin{array}{c}\text { Total suspended } \\
\text { load (mt) }\end{array}$ & $\begin{array}{c}\text { Organic carbon } \\
\text { load (tonnes) }\end{array}$ \\
\hline SSKR-1 & 9.10 .2009 & $16.033^{\circ}$ & $80.873^{\circ}$ & 178 & 0.06 & 0.98 & 19.085 & -21.35 & 0.221 & 2166 \\
\hline SSKR-2 & 11.10 .2009 & $16.033^{\circ}$ & $80.873^{\circ}$ & 81 & 0.06 & 0.91 & 17.815 & -22.22 & 0.017 & 155 \\
\hline SSKR-3 & 13.10 .2009 & $16.033^{\circ}$ & $80.873^{\circ}$ & 64 & 0.08 & 1.08 & 15.840 & -22.27 & 0.0034 & 37 \\
\hline SSKR-4 & 15.10 .2009 & $16.033^{\circ}$ & $80.873^{\circ}$ & 22 & 0.10 & 1.17 & 13.733 & -23.46 & - & - \\
\hline SSKR-5 & 17.10 .2009 & $16.033^{\circ}$ & $80.873^{\circ}$ & 19 & 0.28 & 2.27 & 9.485 & -25.52 & 0.0001 & 2.27 \\
\hline SSKR-8 & 23.10 .2009 & $16.033^{\circ}$ & $80.873^{\circ}$ & 15 & 0.89 & 5.43 & 7.138 & -26.87 & 0.0005 & 27.15 \\
\hline SSKR-9 & 25.10 .2009 & $16.033^{\circ}$ & $80.873^{\circ}$ & 8 & 0.69 & 4.41 & 7.478 & -26.36 & - & - \\
\hline SSKR-10 & 27.10 .2009 & $16.033^{\circ}$ & $80.873^{\circ}$ & 9 & 1.16 & 7.32 & 7.383 & -26.46 & - & - \\
\hline
\end{tabular}

from the particulate matter was ensured by treating the sample with $1 \mathrm{~N} \mathrm{HCl}$ till complete absence of $\mathrm{CO}_{2}$ effervescence.

An elemental analyzer coupled with isotope ratio mass spectrometer (EA-IRMS-Delta V, Finnigan, Germany) was used to measure $\delta^{13} \mathrm{C}_{\text {org }}$ in the particulate matter. The results were expressed relative to Pee Dee Belemnite (PDB) limestone $e^{30}$ as $\delta$-notation. High-purity $\mathrm{CO}_{2}$ was used as a working standard for $\delta^{13} \mathrm{C}_{\text {org }} . \mathrm{CO}_{2}$ gas was calibrated with internal reference materials of glutamic acid, alanine, marine sediment and International Atomic Energy Agency (IAEA) standards. Standard deviation of duplicate analysis and long-term precision of the instrument was within $\pm 0.2 \%$ for carbon. Table 1 presents the analytical results.

The organic carbon and nitrogen concentrations of particulate matter show distinct variations during and after the flood period. During the initial intense flood period both $\mathrm{C}$ and $\mathrm{N}$ contents are low $(0.98 \%$ and $0.06 \%$ respectively; Table 1), increase gradually and reach a maximum of $7.32 \%$ and $1.16 \%$ respectively, during the receding phase of the flood. On the other hand, $\mathrm{C} / \mathrm{N}$ ratios are high (1419) during the initial phase of the flood, and decrease gradually to reach a low of $\sim 7$ during its ebb phase. The $\delta^{13} \mathrm{C}_{\text {org }}$ of particulate matter varies widely between $-21.3 \%$ and $-27.1 \%$ o (Table 1$)$. The $\delta^{13} \mathrm{C}_{\text {org }}$ is enriched $(-21.3 \%$ ) during the initial flood period and is gradually depleted to $-27 \%$ at the ebb phase.

The large temporal variation in $\delta^{13} \mathrm{C}_{\text {org }}$ values $(-21.3 \%$ to $-27.1 \%$ ) and $\mathrm{C} / \mathrm{N}$ ratios (Figure $4 a$ ) indicates changes in the provenance of organic matter (Table 1). The $X-Y$ plot of $\mathrm{C} / \mathrm{N}$ ratio versus $\delta^{13} \mathrm{C}_{\text {org }}$ can be used to characterize organic matter sources ${ }^{18}$. The initial flood period is characterized by high $\mathrm{C} / \mathrm{N}$ ratios and enriched $\delta^{13} \mathrm{C}_{\text {org }}$ values, which progressively trend towards low $\mathrm{C} / \mathrm{N}$ ratios and depleted $\delta^{13} \mathrm{C}_{\text {org }}$ values. By the ebb phase, the $\delta^{13} \mathrm{C}_{\text {org }}$ values and $\mathrm{C} / \mathrm{N}$ ratios are close to $-27 \%$ and 7 respectively, which is typical of $\mathrm{C} 3$ vegetation and freshwater phytoplankton ${ }^{13-15,18,19}$. The $\delta^{13} \mathrm{C}_{\text {org }}$ values during flood period differ significantly nearly by $\sim 8 \%$ o when compared to the Krishna River estuarine particulate matter $(-29.7 \%)^{31}$ collected during the summer monsoon period. 


\section{RESEARCH COMMUNICATIONS}
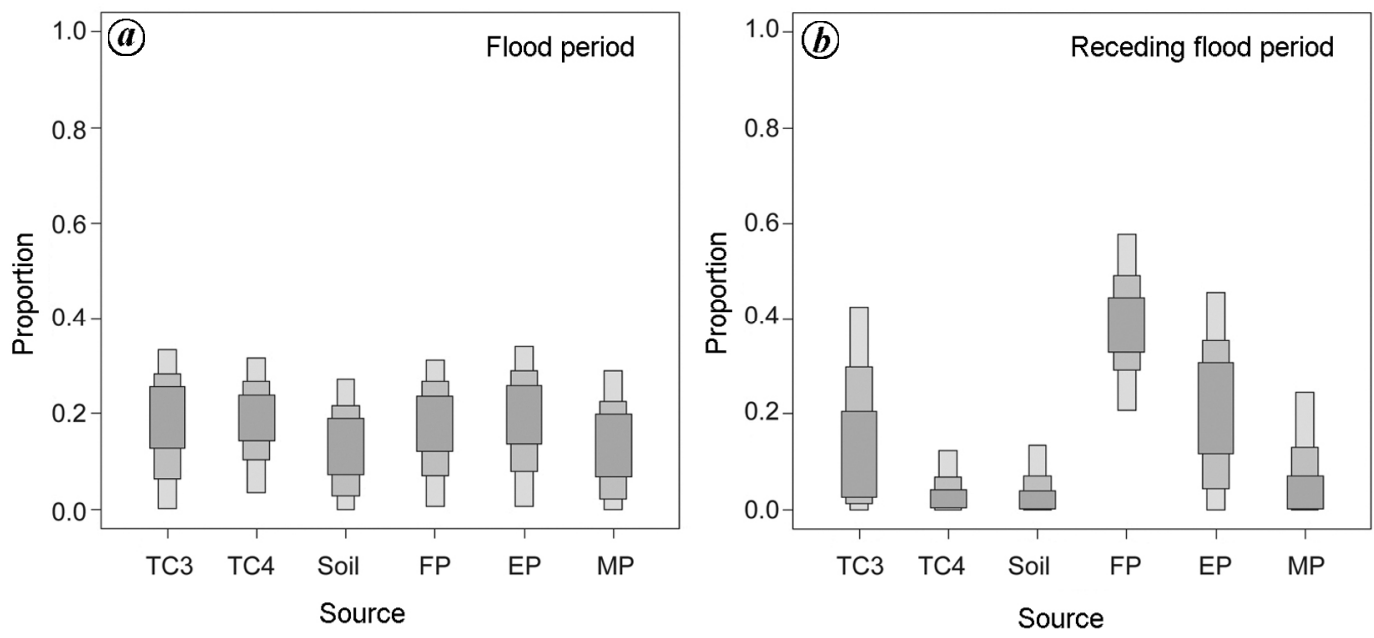

Figure 5. Source material proportional contributions from terrestrial C3 (TC3) and C4 (TC4) plants, soil, freshwater (FP), estuarine (EP) and marine phytoplankton (MP) to particulate matter during (a) flood period and (b) receding flood period. Boxes indicate credibility internals of $97 \%$ and $75 \%$ for contribution from each source.

This isotopic difference suggests a shift in the organic matter provenance during the flood period to $\mathrm{C} 4$-rich vegetation from $\mathrm{C} 3$-rich vegetation and freshwater phytoplankton during the non-flood period. Moreover, in the $X-Y$ plot between $\mathrm{C} / \mathrm{N}$ and $\delta^{13} \mathrm{C}_{\text {org }}$, the intercept along the $\delta^{13} \mathrm{C}_{\text {org }}$ axis at $-27 \%$ (Figure $4 a$ ), close to the Krishna river particulate matter, further supports the provenance shift observed in $\delta^{13} \mathrm{C}_{\mathrm{org}}$ variation during the cycle of the present flood (Figure $4 b$ ).

In order to understand variations of carbon sources and quantify the relative contribution of each source, an isotope mixing model, viz. SIAR (Stable Isotope Analysis in $\mathrm{R}$ ) an open source $\mathrm{R}$ package is used (http://cran.rproject.org). This model has been used to explain carbon source appropriation ${ }^{12,32}$. Carbon in the present samples may have multiple sources such as terrestrial carbon (soil carbon, C3 and C4 vegetation) and aquatic carbon (freshwater, estuary and marine). The end-member carbon isotopic value of each source is required for model calculation. As $\delta^{13} \mathrm{C}_{\text {org }}$ values for the Krishna River Basin sedimentary organic matter were not available for mixing calculations, we have utilized the $\delta^{13} \mathrm{C}_{\text {org }}$ data available for the adjacent Godavari River Basin ${ }^{12}$, which has a similar source area. The calculated proportions of carbon from different sources indicate that soil carbon, C3 and C4 vegetation together contribute highest carbon (50\%; Figure $5 a$ ) to the Krishna River particulate matter during flood. While carbon derived from aquatic sources (freshwater $40 \%$, estuary 20 , marine $10 \%$ ) dominates during the receding phase of floods compared to terrestrial sources (C3 20\%, C4 5\%, soil 5\%; Figure $5 b$ ). The terrestrial carbon from mixed sources during the flood period is replaced with carbon from aquatic sources during the receding phase of flood.

The traditional major crops in the semi-arid region of peninsular India are jowar (Sorghum), corn (Zea mays L.) and millet (Pennisetum americanum), which are typical $\mathrm{C} 4$ plants $^{33}$. These traditional crops have been replaced with rice, a C3 plant, near the reservoirs. In the deltaic Krishna region which receives moderate rainfall and assured supply of water from the reservoirs, the cultivated crops are rice (Oryza sativa), sugarcane (Saccharum sp.) and commercial crops like cotton, ground nut (Arachis hypogaea) and chillies (Capsicum spp.) $)^{34,35}$. Rice is a typical C3-type crop, while sugarcane is a C4-type crop.

The $\delta^{13} \mathrm{C}_{\text {org }}$ values (-21.4\%o to $-23.5 \%$ ) of suspended matter in the flood water suggest that terrestrial carbon derived from C3- and C4-type crops in the semi-arid region contributes significantly to the particulate matter in River Krishna during the flood period. The high $\mathrm{C} / \mathrm{N}$ ratios (14-19; Table 1) suggest organic matter was degraded (Figure 4). The $\delta^{13} \mathrm{C}_{\text {org }}$ values as well as $\mathrm{C} / \mathrm{N}$ ratios of particulate organic matter in the receding flood waters suggest that an alternate source for organic matter is possible. The depleted $\delta^{13} \mathrm{C}_{\text {org }}$ values $(-25.5 \%$ to $-27.1 \%$ ) suggest that organic carbon is mainly from $\mathrm{C} 3$ vegetation $(20 \%$ Figure $5 \mathrm{~b}$ ). During ebb phase of the flood, a reduction in $\mathrm{C} 4$ vegetation (18\% to $5 \%$ ) also supports dominance of C3-type organic matter. Very low $\mathrm{C} / \mathrm{N}$ ratios (7-9; Table 1) suggest fresh leaf litter, agriculture residues and phytoplankton. Microscopic examination of SPM indicates that organic matter is composed mainly of fragments of rice plants and foliage. The mixing calculations show that the organic carbon is derived from aquatic sources (freshwater $40 \%$ and estuarine 20\%) during the receding phase of floods.

During the 2009 monsoon (June-October), particulate matter discharged by River Krishna at Wadenapalli was $\sim 2.54 \mathrm{mt}$ of which $2.30 \mathrm{mt}$ was discharged during October 2009 (refs 26, 27). Most of this particulate load ( $\sim 94 \%$ of the total) was discharged by the river in the 


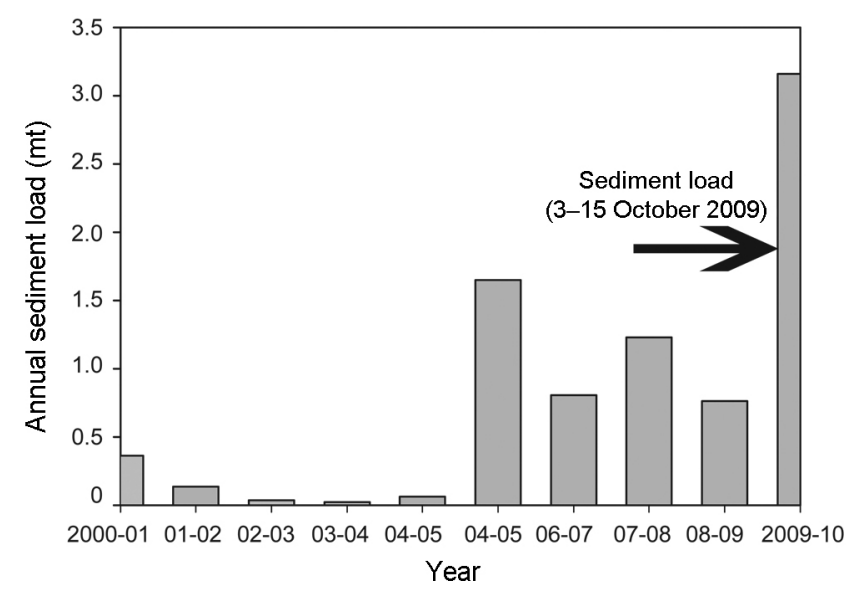

Figure 6. Annual sediment load carried by River Krishna at Wadenapalli ${ }^{26}$. The arrow represents total sediment load during the flood based on particulate matter collected in this study.

first ten days of October during intense flooding (Figure 6) ${ }^{26,27}$. Our calculations show that the amount of total sediment and organic carbon discharged during the first half of October, when the flooding event occurred, is $1.9 \mathrm{mt}$ and $0.02 \mathrm{mt}$ respectively (Table 1 ).

The sediment discharge during the flood period is threefold that of total sediment discharged during 2000$2005(0.63 \mathrm{mt})$ to the western BoB by River Krishna (Figure 6). Thus extreme precipitation and associated floods are important events wherein during a short period of time large amounts of riverbed sediments and particulate organic matter are transferred to the coastal regions. The present-day transfer of sediments and organic matter, therefore, depends on the area of flooding and release of waters from dams and reservoirs.

1. Ting-Hsuan, H., Yu-Han, F., Pei-Yi, P. and Arthur Chen, C. T., Fluvial carbon fluxes in tropical rivers. Curr. Opin. Environ. Sustain., 2012, 4, 162-169.

2. Farnsworth, K. L. and Milliman, J. D., Long-term fluvial sediment delivery to the ocean: effect of climatic and anthropogenic change. Global Planet. Change, 2003, 39, 53-64.

3. Bouwer, L. M., Aerts, J. C. J., Droogers, P. and Dolman, A. J., Detecting the long-term impacts from climate variability and increasing water consumption on runoff in the Krishna river basin (India). Hydrol. Earth Syst. Sci., 2006, 10, 703-713.

4. Biggs, T. W. et al., Closing of the Krishna Basin: irrigation development, stream flow depletion and macroscale hydrology. In IWMI Research Report 111, International Water Management Institute, Colombo, Sri Lanka, 2007, p. 44.

5. Gamage, N. and Smakhtin, V., Do river deltas in East India retreat? A case of the Krishna Delta. Geomorphology, 2009, 103, 533-540.

6. Prahl, F. G., Ertel, J. R., Goñi, M. A., Sparrow, M. A. and Eversmeyer, B., Terrestrial organic carbon contributions to sediments on the Washington margin. Geochim. Cosmochim. Acta, 1994, 58, 3035-3048.

7. Bianchi, T., Mitra, S. and McKee, B., Sources of terrestrially derived organic carbon in lower Mississippi River and Louisiana shelf sediments: implications for differential sedimentation and transport at the coastal margin. Mar. Chem., 2002, 77, 211-223.
8. Blair, N. E., Leithold, E. L., Ford, S. T., Peeler, K. A., Holmes, J. C. and Perkey, D. W., The persistence of memory: the fate of ancient sedimentary organic carbon in a modern sedimentary system. Geochim. Cosmochim. Acta, 2003, 67, 63-73.

9. Gordon, E. S. and Goñi, M. A., Sources and distribution of terrigenous organic matter delivered by the Atchafalaya River to sediments in the northern Gulf of Mexico. Geochim. Cosmochim. Acta, 2003, 67, 2359-2375.

10. Galy, V., Eglinton, T., France-Lanord, C. and Sylva, S., The provenance of vegetation and environmental signatures encoded in vascular plant biomarkers carried by the Ganges-Brahmaputra rivers. Earth Planet. Sci. Lett., 2011, 304, 1-12.

11. Ramaswamy, V., Gaye, B., Shirodkar, P. V., Rao, P. S., Chivas, A. R., Wheeler, D. and Thwin, S., Distribution and sources of organic carbon, nitrogen and their isotopic signatures in sediments from the Ayeyarwady (Irrawaddy) continental shelf, northern Andaman Sea. Mar. Chem., 2008, 111, 137-150.

12. Krishna, M. S., Naidu, S. A., Subbaiah, Ch. V., Gawade, L., Sarma, V. V. S. S. and Reddy, N. P. C., Sources, distribution and preservation of organic matter in a tropical estuary (Godavari, India). Estuaries Coasts, 2015, 38, 1032-1047.

13. Smith, B. N. and Epstein, S., Two categories of ${ }^{13} \mathrm{C} /{ }^{12} \mathrm{C}$ ratios for higher plants. Plant Physiol., 1971, 47, 380-384.

14. Fry, B. and Sherr, E. B., $\delta^{13} \mathrm{C}$ measurements as indicators of carbon flow in marine and freshwater ecosystems. Contrib. Mar. Sci., 1984, 27, 15-47.

15. Leithold, E. and Blair, N., Watershed control on the carbon loading of marine sedimentary particles. Geochim. Cosmochim. Acta, 2001, 65, 2231-2240.

16. Bender, M. M., Variations in the ${ }^{13} \mathrm{C} /{ }^{12} \mathrm{C}$ ratios of plants in relation to the pathway of photosynthetic carbon dioxide fixation. Phytochemistry, 1971, 10, 1239-1244.

17. Emerson, S. and Hedges, J. I., Processes controlling the organic carbon content of open ocean sediments. Paleoceanography, 1988, 3, 621-634.

18. Lamb, A. L., Wilson, G. P. and Leng, M. J., A review of coastal palaeoclimate and relative sea-level reconstructions using $\delta^{13} \mathrm{C}$ and $\mathrm{C} / \mathrm{N}$ ratios in organic material. Earth-Sci. Rev., 2006, 75, 2957.

19. Salomons, W. and Mook, W. G., Field observations of the isotopic composition of particulate organic carbon in the southern North Sea and adjacent estuaries. Mar. Geol., 1981, 41, M11-M20.

20. Prahl, F. G., Bennett, J. T. and Carpenter, R., The early diagenesis of aliphatic hydrocarbons and organic matter in sedimentary particulates from Dabob Bay, Washington. Geochim. Cosmochim. Acta, 1980, 44, 1967-1976.

21. Ramesh, R. and Subramanian, V., Temporal, spatial and size variation in the sediment transport in the Krishna river basin. J. Hydrol., 1988, 98, 53-65.

22. Panda, D. K., Kumar, A. and Mohanty, S., Recent trends in sediment load of the tropical (Peninsular) river basins of India. Global Planet. Change, 2011, 75, 108-118.

23. Gupta, H., Shuh-Ji Kao and Dai, M., The role of mega dams in reducing sediment fluxes: a case study of large Asian rivers. J. Hydrol., 2012, 464-465, 447-458.

24. Nageswara Rao, K., Subraelu, P., Naga Kumar, K. Ch. V., Demudu, G., Hema Malini, B., Rajawat, A. S. and Ajai, Impacts of sediment retention by dams on delta shoreline recession: evidences from the Krishna and Godavari deltas, India. Earth Surf. Process Landforms, 2010, 35, 817-827.

25. Anon., Integrated Hydrological Data Book, Central Water Commission. Government of India, 2009, p. 381.

26. Anon., Integrated Hydrological Data Book, Central Water Commission. Government of India, 2012, p. 680.

27. Anon., 2009, Managing Historic Flood in the Krishna River Basin. An Experience of Averting Catastrophe, Andhra Pradesh Water Resources Development Corporation Report, 2009, p. 123. 
28. Kumar, R., Singh, R. D. and Sharma, K. D., Water resources of India. Curr. Sci., 2005, 89, 794-811.

29. Sarma, V. V. S. S., Arya, J., Subbaiah, C. V., Naidu, S. A., Gawade, L., Kumar, P. P. and Reddy, N. P. C., Stable isotopes of carbon and nitrogen in suspended matter and sediments from the Godavari estuary. J. Oceanogr., 2013, 68, 307-319.

30. Coplen, T. B., New guidelines for reporting stable hydrogen, carbon and oxygen isotope-ratio data. Geochim. Cosmochim. Acta, 1996, 60, 3359-3360

31. Sarma, V. V. S. S. et al., Distribution and sources of particulate organic matter in the Indian monsoonal estuaries during monsoon. J. Geophys. Res-Biogeosci., 119, 2095-2111.

32. Parnell, A., Inger, R., Bearhop, S. and Jackson, A. L., Source partitioning using stable isotopes coping with too much variation. PLoS ONE, 2010, 5, 9672.

33. Kaplan, J. O., Krumhardt, K. M., Ellis, E. C., Ruddiman, W. F., Lemmen, C. and Goldewijk, K. K., Holocene carbon emissions as a result of anthropogenic land cover change. Holocene, 2011, 21, 775-791.

34. Subramaniam, A. R. and Sambasiva Rao, A., Scheduling irrigation based on some climatic indices for crops in Maharashtra of western peninsular India. Irrigation and Water Allocation. In Proceedings of the Vancouver Symposium, August 1987, IAHS Publ. No. 169,1987 , pp. 153-162.

35. Leff, B., Ramankutty, N. and Foley, J. A., Geographic distribution of major crops across the world. Global Biogeochem. Cycles, 2004, 18, GB1009; doi:10.1029/2003GB002108.

36. Rajeevan, M., Bhate, J., Kale, J. D. and Lal, B., Development of a high resolution daily gridded rainfall data set for the Indian region. IMD Meteorological Monograph No. Climatology 22/2005, 2006, India Meteorological Department, Pune, 2006.

37. Rajeevan, M., Bhate, J., Kale, J. D. and Lal, B., High resolution daily gridded rainfall data for the Indian region: analysis of break and active monsoon spells. Curr. Sci., 2006, 91, 296-306.

ACKNOWLEDGEMENTS. We thank the Director, National Institute of Oceanography (NIO) for permission to publish this manuscript. We also thank the anonymous reviewer for constructive comments that helped improve the manuscript; Drs D. Shankar and Suprit Kumar (NIO, Goa) for help while preparing the annual precipitation map of the Krishna River basin from voluminous database; Dr M. Ramakrishna (NIO, Vizag) for help with the SIAR program; Ms Anandi (NIO, Goa) for assistance during analytical work in the laboratory and Mr T. Sujit Babu for assistance in sampling during floods. This is NIO's contribution No. 6457.

\section{Unique breeding activity and oviposition in Annandale's high-altitude tree frog, Kurixalus naso (Annandale, 1912) in Meghalaya, North East India}

\author{
P. W. Shangpliang ${ }^{1, *}$, R. N. K. Hooroo ${ }^{2}$ and \\ S. K. Dutta ${ }^{2}$ \\ ${ }^{1}$ Department of Zoology, North Eastern Hill University, \\ Shillong 793 022, India \\ ${ }^{3}$ Nature Environment and Wildlife Society, Angul 759 123, India
}

The present study highlights the unique characteristics of the breeding activity and oviposition of Annandale's high-altitude tree frog, Kurixalus naso (Annandale, 1912) at Mawsynram, Meghalaya, North East India. After the cold, dry, winter months (SeptemberJanuary), the first rainfall in February triggers the onset of a short breeding activity of the species, which lasts for 3-4 weeks during February to March. The first shower causes an increase in soil moisture content and decrease in soil temperature. Immediately after the first showers, males make their advertisement calls, followed by females engaging in amplexus with the males and ovipositing in the moist soil. The females come only once to the breeding site and leave after mating; parental care is provided by the males. Multiple amplecting pairs at the breeding site are seen inside the burrows and some are observed to amplect in the open soil surface, lasting for 5-6 h. No aggregation and competition among the males is observed. The amplecting females lay eggs inside the excavated burrows and the males, using their hind limbs, expose the eggs by pushing them to the mouth of the burrowing hole. Sometimes, the females oviposit at the base of hollow tree trunks and occasionally in the open soil surface. The eggs are mixed with the soil and they resemble perhaps masquerade as seeds. Most frogs display a biphasic life cycle. However, $K$. naso shows a distinct non-aquatic oviposition with aquatic larva. Further, soil moisture content and temperature may support the development of embryos in open soil surfaces and burrows.

Keywords: Amplexus, breeding, burrows, Kurixalus naso, oviposition.

ANURANS have the highest diversity of breeding behaviours among all vertebrate taxa $a^{1,2}$. They display a biphasic life cycle and breed in a variety of habitats such as temporary rainfed ponds, permanent ponds, cemented tanks, streams and rivers. In addition, they select different habitats, especially those that have vegetation cover, as it provides shelter and calling sites ${ }^{3}$. Anurans may be

*For correspondence. (e-mail: shangpliang1992@gmail.com) 